\title{
Sedative Effect of Clove Oil and 2-Phenoxyethanol on Marine Clownfish (Amphiprion ocellaris) and Freshwater Swordfish (Xiphophorus helleri)
}

\author{
Müge Aliye Hekimoğlu*, Cüneyt Süzer, Şahin Saka and Kürşat Firat \\ Aquaculture Department, Faculty of Fisheries, Ege University, Bornova 35100, \\ Izmir, Turkey
}

\section{A B S T R A C T}

This study's objective was to determine effect of two different anaesthetics 2-phenoxyethanol and clove oil on the sedation of some aquarium fish species. The induction and recovery times were determined at five stages of melanistic and not melanistic clownfish (Amphiprion ocellaris) and different sexes of Swordfish (Xiphophorus helleri). Clownfish were tested with $0.4,0.6$ and $0.8 \mathrm{ml} / 1$ phenoxyethanol and $0.5,1$ and $1.5 \mathrm{ml} / 1$ clove oil. Swordfish were tested with 1,3 and $5 \mathrm{ml} / 1$ phenoxyethanol and 2, 4, $6 \mathrm{ml} / 1$ clove oil. For short-term application the safe dose for clownfish was $0.4 \mathrm{ml} / 1$ phenoxyethanol and $1 \mathrm{ml} / 1$ clove oil. For swordtail fish, the ideal amount of phenoxyethanol was $5 \mathrm{ml} / 1$ and $6 \mathrm{ml} / 1$ clove oil. These safe doses reduce handling stress and mortality.

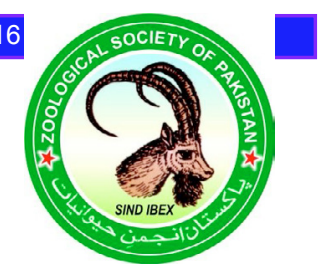

CrossMark \&lick for updates

\section{INTRODUCTION}

A nesthetic substances, which are used in every stage of aquaculture, decrease the level of stress on fish during applications. This situation removes negative effects, physical traumas and losses (Summerfelt and Smith, 1990; Soto and Burhan-ud-Din, 1995; Munday and Wilson, 1997; Ross and Ross, 2008). An ideal anesthetic should induced in $3 \mathrm{~min}$ and recover in $5 \mathrm{~min}$ or less for aquaculture studies. It should not endanger animal and human health. People usually prefer low costs anaesthetic agent (Marking and Meyer, 1985; Ross and Ross, 2008).

Clove oil and 2-phenoxyethanol are among the mostly preferred local anesthetics in some aquaculture practices. 2-Phenoxyethanol is a colorless, slightly aromatic and oily liquid which can be applied directly and used for fish extensively (Ross and Ross, 2008; Tamaru et al., 2001). Clove oil is extracted from the clove plant. It is aromatic, slightly oily, local anaesthetic. This agent can dissolve in temperate-water easily, but it should be used with ethanol for a cold-water condition (Park et al., 2008). Clove oil has many benefits such as being antibacterial, antiviral, and natural analgesic agent. Moreover, it is economic and is not being harmful to animal health. That's why make clove oil a widely preferred substance (Keene et al., 1998; Tort et al., 2002; Ross and Ross, 2008).

\footnotetext{
Corresponding author: mugehekimoglu@gmail.com 0030-9923/2017/0006-2209 \$ 9.00/0

Copyright 2017 Zoological Society of Pakistan
}

Clownfish species are great importance among marine aquarium fish. Within recent years, the financial value of ornamental fish has increased due to the increasing demand for sea aquariums (Olivotto et al., 2003; Avella et al., 2007; Ajith Kumar et al., 2010; Dhaneesh et al., 2012). They were collected from their coral reefs until quite recently, but they have been started to be produced in closed systems today which include all the conditions for fish growth phases (Allen, 1980; Haschick, 1998; Pomeroy and Balboa, 2004; Gopakumar et al., 2001). The cultured clownfish reaches to $5 \mathrm{~cm}$ and costs $\$ 0.53$ and is sold at a price of $\$ 2.25$ within 120 days (Pomeroy and Balboa, 2004). This fish was the most common ornamental species covering $15.6 \%$ of the total number of fish exported worldwide during 1997-2002 (Wabnitz et al., 2003). Cultivation of tropical marine aquarium fish, which are a significant part of aquaculture studies, is an important agriculture and industry brunch. It is known that ornamental marine aquarium fish are exposed to manipulation in every phase of cultivation especially before their international transportation. There are many research about this fish such as broodstock management and spawning (Kumar and Balasubramanian, 2009), biology (Yasir and Qin, 2009), feeding (Yasir and Qin, 2010; Olivotto et al., 2011).

Studies on sedation and anesthesia are not abundant in the clownfish Amphiprion sp. Therefore, in this study the efficacy of two different sedative and anaesthetic substances on clownfish which show melanistic and not melanistic growth has been identified. It is expected to 
provide helpful information on the sedation procedure of Melanosis and not Melanosis in clownfish in the aquaculture facilities.

Swordtails have often been used in behavior ecology, genetics, biology (Kayım et al., 1999) and biogeography (Gutierrez-Rodriguez et al., 2007) and is considered an ideal species for the toxicological studies of endocrine-disrupting chemicals (Kwak et al., 2001) due to its great advantages, which include the small size of species and the ease of raising them, a short generation time and distinct sexual characteristics

. Besides all these, swordtail fish, which are of great importance among aquarium fish, are also among species with financial value due to their colors and tail structures (Tamaru et al., 2001). In this study, effort was made to explain in a detailed manner the reaction of male and female swordtail fish to anesthetic applications carried out with 2-Phenoxiethanol and clove oil, which enable many scientific studies to be carried out.

\section{MATERIALS AND METHODS}

\section{Anaesthetic agents}

In the tests, commercial phenoxyethanol and clove oil were used. Phenoxyethanol was purchased from SigmaAldrich. Purity of the phenoxyethanol was reported as 99.9\%. Clove oil was purchased from a herbalist (Kardelen Comp., Turkey). The content of the clove oil was analyzed in the laboratory of Pharmacy, Faculty of Ege University in Turkey. Its content was reported as $96.1 \%$ eugenol, $2.41 \%$ Caryophyllene, $0.29 \%$, a-Selinene, 0.27 Isochiapin B.

\section{Experiment fish and keeping conditions}

After 210 clownfish and 420 swordfish were brought from a commercial ornamental fish breeders facility (Orta Dogu Aquarium Comp., Izmir); all of them were randomly placed in five glass aquariums $(47 \times 37 \times 29 \mathrm{~cm})$ until the experiment day. All aquariums water temperature were kept $23 \pm 0.5^{\circ} \mathrm{C}$, pH were $8-8.5$ for clownfish, 7-7.5 for swordfish. Illumination was used in the aquariums for 8 h. The air was delivered to each aquarium through central air engine. Fish were fed with commercial fish food ad libitum every day. Feces were removed immediately.

The clownfish were separated according to their body color; melanosis (blackish brown color) and not melanosis (light reddish color). The mean weight and total length were measured $3.21 \pm 0.62 \mathrm{~g}$ and $5.36 \pm 0.38$ $\mathrm{cm}$ of melanosis group, respectively. The not melanosis group's measurements were $3.47 \pm 0.65 \mathrm{~g}$ of mean weight and $4.63 \pm 0.60 \mathrm{~cm}$ of mean total length. Swordfish were measured $3.15 \pm 0.85 \mathrm{~g}$ mean weight and $6.72 \pm 0.24$ $\mathrm{cm}$ total length for male; $3.67 \pm 0.86 \mathrm{~g}$ mean weight and $4.36 \pm 0.58 \mathrm{~cm}$ total length for female, respectively.

\section{Experiment design}

Feeding was stopped before $24 \mathrm{~h}$ for experiment day. The sedative agent phenoxyethanol was mixed with onelitre water for induction in a small observation aquarium. Clove oil was used after being dissolved in ethanol at a rate of 1/9 (1:10 ratio of clove oil: ethanol) as described by Anderson et al. (1997). Melanosis and not melanosis groups were exposed to 3 doses of clove oil $(0.5,1$ and $1.5 \mathrm{ml} / \mathrm{l}$ ) and 3 doses of phenoxyethanol 0.4, 0.6 and 0.8 $\mathrm{ml} / \mathrm{l}$. Swordfish were exposed to 1,3 , and $5 \mathrm{ml} / 1$ doses of phenoxiethanol and 2, 4 and $6 \mathrm{ml} / 1$ clove oil.

Ten fish were used for every agent dose and replicates. Induction and recovery behaviour were recorded with a

Table I.- Description of the respective stage of anaesthesia and recovery in clownfish (modified from Ross and Ross, 2008).

\begin{tabular}{|c|c|c|c|}
\hline & Stage & Description & Physiological and behavioural signs \\
\hline \multirow[t]{5}{*}{ Induction } & A & Light sedation & Slow swimming, decreased reactivity to external stimuli, body balance is normal. \\
\hline & $\mathrm{B}$ & Deep sedation & $\begin{array}{l}\text { Suppression of a complete loss of reactivity except strong external stimuli operculum } \\
\text { slight decrease in the movement partial body balance loss. }\end{array}$ \\
\hline & $\mathrm{C}$ & Light anaesthesia & $\begin{array}{l}\text { Low turning to one side but still reaction to external stimuli particularly in the fish, } \\
\text { opercular movements continued. }\end{array}$ \\
\hline & $\mathrm{D}$ & Deep anaesthesia & $\begin{array}{l}\text { Lying on one side without movement, opercular movements are very slow usually } \\
\text { difficult to see. }\end{array}$ \\
\hline & $\mathrm{E}$ & Surgical anaesthesia & Total loss of reaction to even massive stimulation. \\
\hline \multirow[t]{5}{*}{ Recovery } & A & Deep anaesthesia & Body immobilized but opercular movements just starting. \\
\hline & $\mathrm{B}$ & Anaesthesia & Regular opercular movements. \\
\hline & $\mathrm{C}$ & Deep sedation & Gross body movements beginning. \\
\hline & $\mathrm{D}$ & Light sedation & Preanesthetic appearance. \\
\hline & $\mathrm{E}$ & Normal & Equilibrium regained. \\
\hline
\end{tabular}


video camera. The criteria of induction and recovery were shown in Table I. The experiment was repeated three times for each dose. Measurements were made by using a stopwatch and every phase transition was identified separately for induction and recovery. After the experiment, the fish were placed in aquaria filled with clean water and aerated with an air pump. The observation were continued until they intake food. The experimental fish were monitored for any abnormal behaviour and or mortality during a week.

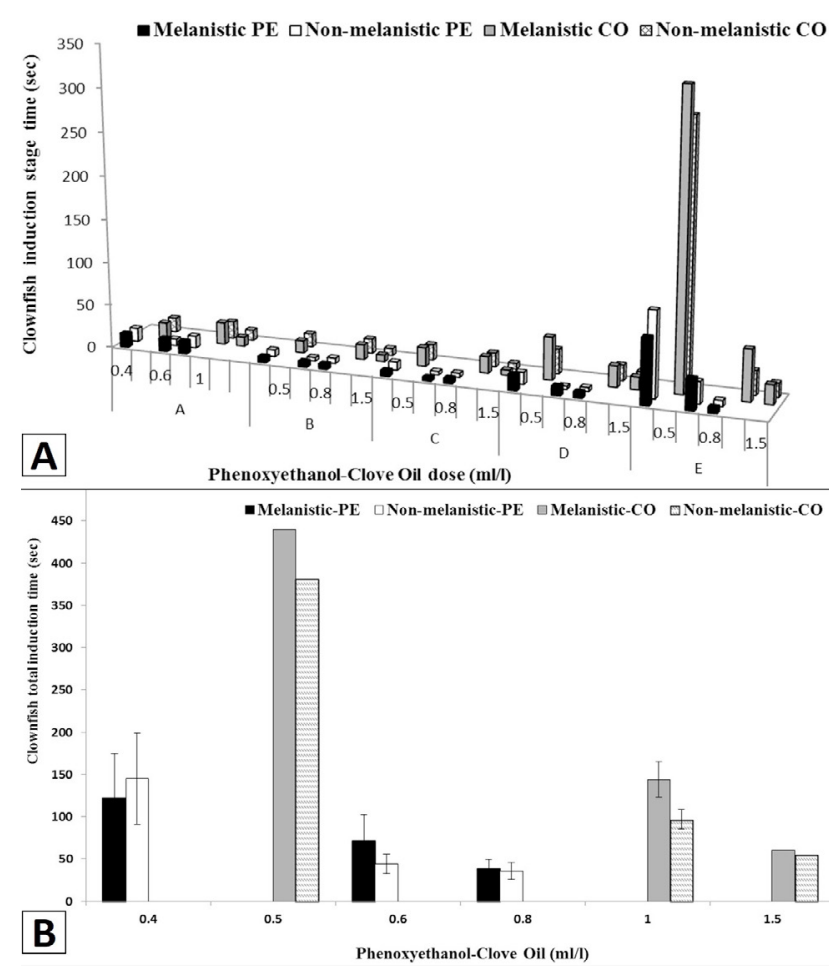

Fig. 1. Induction stage time (A) and total induction time (B) of melanistic and not melanistic clown fish which were applied phenoxyethanol and clove oil $(\mathrm{Mean} \pm \mathrm{SD})$.

\section{Statistical analysis}

All the statistical analysis was performed using SPSS 15.0 for Windows. Differences between agent doses consisted with Kruskal-Wallis. Statistical comparisons were made between the clove oil and phenoxyethanol exposed groups within melanosis and not melanosis groups and then male-female swordfish groups by using the non-parametric Mann-Whitney U-test.

\section{RESULTS}

It was found out that there were no deaths in the week following the test of the two anesthetic substances and it was found that the fish fed in the same day. During the procession, the fish reacted to anesthetics differently in terms of swimming. In this context, the fish put in the phenoxyethanol container swam rapidly due to abnormal swimming behavior. In the group to which was applied clove oil, the fish did not show abnormal behaviors and induced following the normal swimming behavior when put in water.

\section{Clownfish}

The induction stage time (Fig. 1A) and total induction time (Fig. 1B) of clownfish in phenoxyethanol and clove oil application is shown in Figure 1; whereas, Figure 2 shows recovery stage times (Fig. 2A) and total recovery times (Fig. 2B) of clownfish in phenoxyethanol and clove oil application.

- Melanistic PE aNon-melanistic PE $₫$ Melanistic CO $\square$ Non-melanistic CO
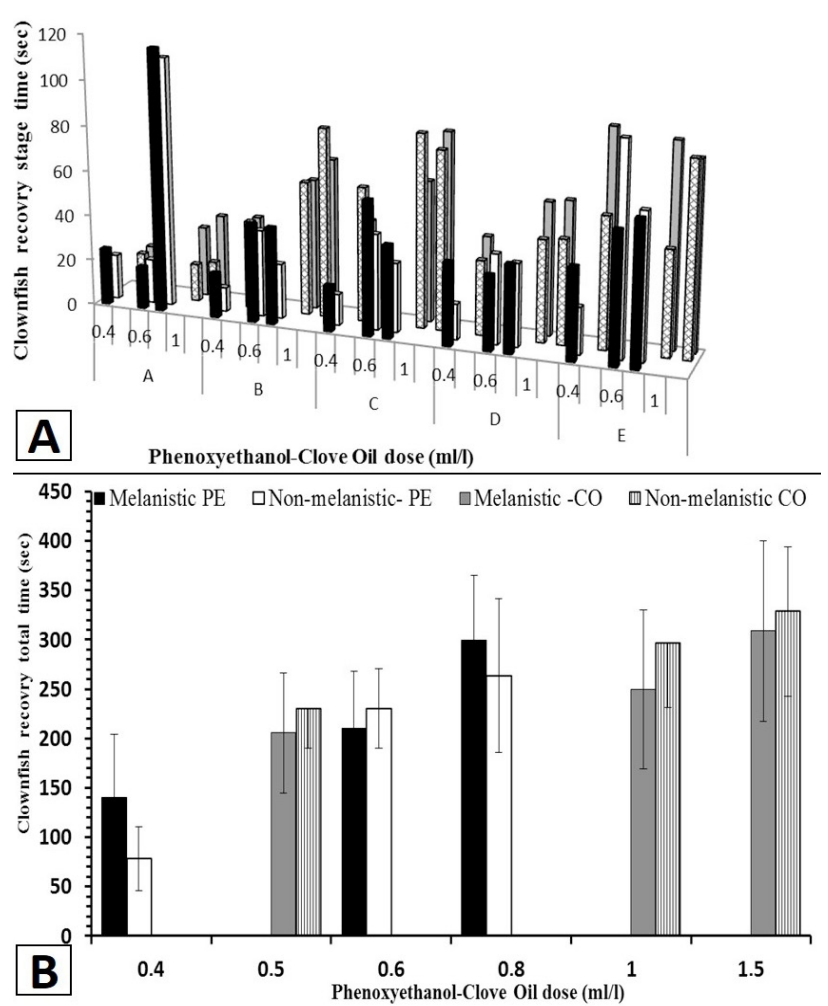

Fig. 2. Recovery stage times (A) and total recovery times (B) of not melanistic and melanistic clownfish which were applied phenoxyethanol and clove oil (Mean $\pm \mathrm{SD})$.

In the assessment, it was found out that there were differences between doses $(0.4,0.6,0.8 \mathrm{ml} / \mathrm{L})$ regarding the total induction time of both melanistic and not melanistic groups $(p<0.05)$. Also when melanistic and not melanistic clownfish were compared by each test dose, a difference was determined between the total induction 
times in 0.4 and $0.6 \mathrm{ml} / \mathrm{L}$. test dose $(\mathrm{p}<0.05)$, but there was no difference between the dose groups in $0.8 \mathrm{ml} / \mathrm{L}$ test dose $(\mathrm{p}>0.05)$.

When the recovery times of the fish were assessed, it was also found out that there was a difference in total recovery times of both not melanistic clownfish and melanistic clownfish $(\mathrm{p}<0.05)$. Together with this, when melanistic and not melanistic clownfish were compared by each test dose, a difference was found in $0.4 \mathrm{ml} / \mathrm{L}$ test dose $(\mathrm{p}<0.05)$, whereas there was no difference in 0.6 and 0.8 $\mathrm{ml} / \mathrm{L}$ test dose $(\mathrm{p}>0.05)$.

In the application of clove oil, the times of induction phase transition of melanistic and not melanistic fish were shown in Figure 1A and total induction times were shown in Figure 1B. Similarly, times of recovery phase transition were shown in Figure 2A and total recovery times were shown in Figure 2B.
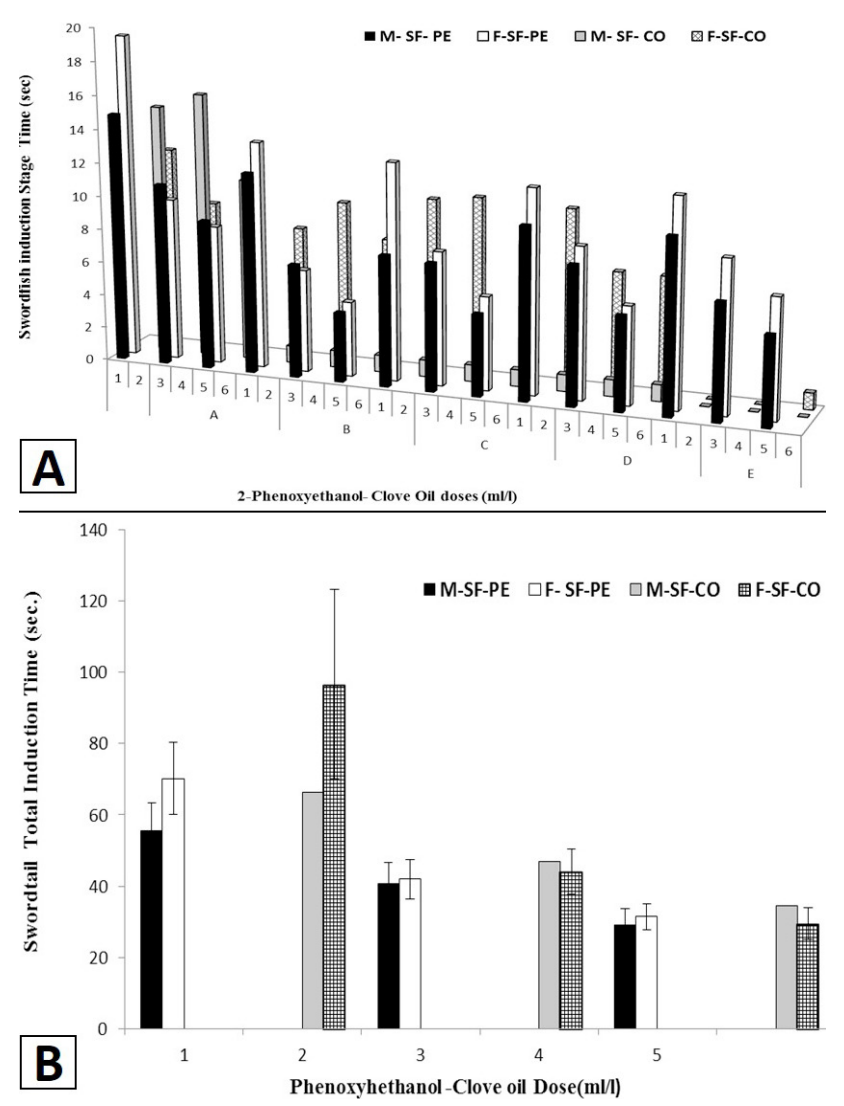

Fig. 3. Intermediate induction stage time (A) and total induction times (B) of female and male swordtail fish which were applied to 2-phenoxiethanol and clove oil (Mean \pm SD).

In the clove oil test, there was a difference between dose $(0.5,1,1.5)$ in terms of total induction times of both melanistic and not melanistic clownfish $(\mathrm{p}<0.05)$. Also when melanistic and not melanistic clownfish were compared by each test dose, there was not a difference in $0.5 \mathrm{ml} / \mathrm{L}$ dose in terms of total induction times $(\mathrm{p}>0.05)$, but in 1 and $1.5 \mathrm{ml} / \mathrm{L}$ test dose a difference between the groups was identified $(\mathrm{p}<0.05)$.

When the recovery times of the fish were assessed, a difference between test dose in terms of total recovery times of both melanistic and melanistic clownfish was found $(p<0.05)$. Also, when recovery of melanistic and melanistic clownfish was compared, it was found that the difference in the group which was applied $0.5 \mathrm{ml} / \mathrm{L}$. The dose was insignificant; however there was a difference between recovery times the individuals in the group which was applied to 1 and $1.5 \mathrm{ml} / \mathrm{L} .(\mathrm{p}<0.05)$.

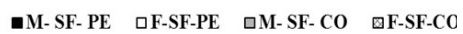
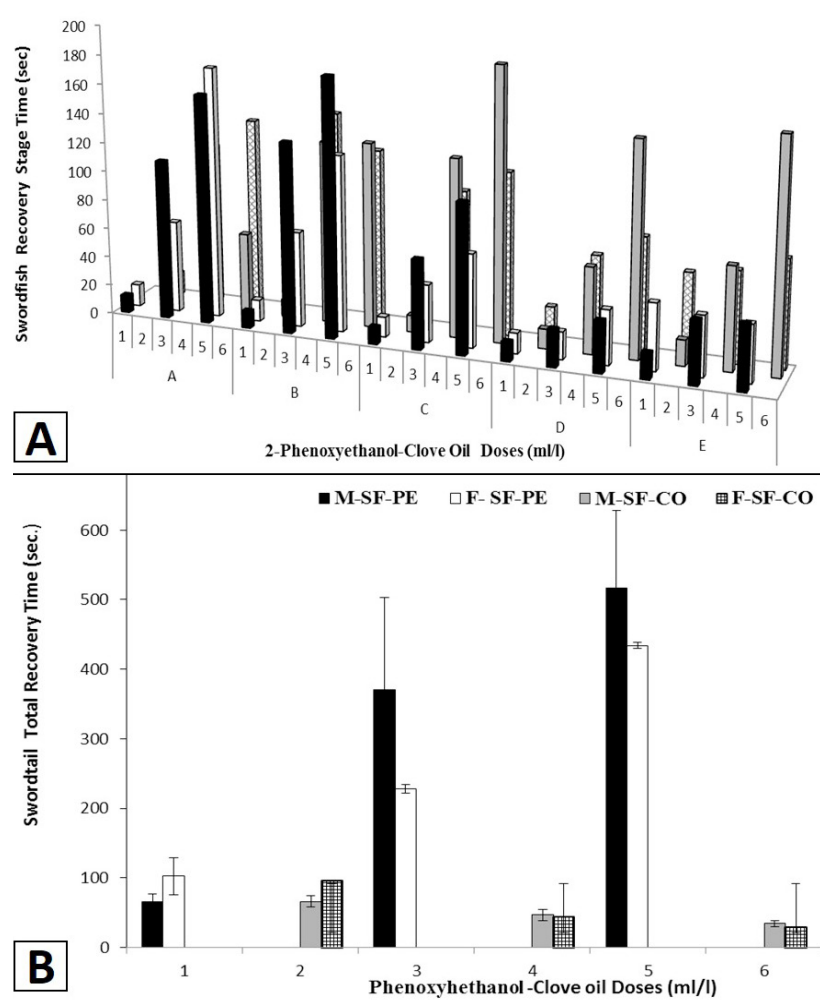

Fig. 4. Intermediate recovery stage times (A) and total recovery times $(\mathrm{B})$ of female and male swordtail fish which were applied to phenoxyethanol and clove oil.

\section{Swordfish}

In phenoxyethanol application, induction phase times of swordtail fish were shown in Figure 3A and total induction times were shown in Figure 3B. Similarly, recovery phase times were shown in Figure 4A and total recovery times were shown in Figure 4B. 
In the assessment, a difference between the total induction times of female and male individuals in 2 -phenoxiethanol dose was found $(p<0.05)$. A similar situation was also found for male individuals $(p<0.05)$. Also, when each dose was assessed one by one, a difference was not determined between the induction times of female and male individuals $(\mathrm{p}>0.05)$.

When the recovery times of the fish exposed to phenoxyethanol were assessed, it was found that there was a difference in total recovery times of female and male individuals in themselves in all concentrations/ doses $(p<0.05)$. Besides, variability in female and male individuals' recovery among doses was identified. Differences were found in all application doses $(\mathrm{p}<0.05)$. In clove-oil applications, induction times of swordtail fish were shown in Figure $3 \mathrm{~A}$ and total recovery times were shown in Figure 3B. Similarly, recovery times were shown in Figure 4A and total recovery times were shown in Figure 4B.

In the application carried out with clove oil, a difference between female and male individuals' induction times among doses was found $(p<0.05)$. Together with this, when each dose was assessed one by one, it was found that there was a difference between induction times of male and female individuals in 2 and $6 \mathrm{ml} / \mathrm{L}$ dose/ concentrations $(\mathrm{p}<0.05)$.

When recovery times of the fish were assessed, a difference between female and male individuals for all doses was found $(\mathrm{p}<0.05)$. In $4 \mathrm{ml} / \mathrm{L}$. clove oil application, there was not a difference between the recovery times of female and male individuals $(p>0.05)$, yet in other application doses, differences were identified $(\mathrm{p}<0.05)$.

\section{DISCUSSION}

When fish are exposed to long-term stress in aquaculture environments, they are affected adversely (Roos and Roos, 2008). For this reason, anesthetic substances have been a subject of study for many marine and freshwater fish species. As a result of the studies, it was found that if inappropriate dose of anesthetics were applied, death or stress-based problems might be encountered due to being exposed to long-term or the inappropriate dose (Feng et al., 2011; Hasan et al., 2013). Abiotic factors, biotic factors, anesthetic choice and application conditions should be taken into consideration when fish are induced (Iversen et al., 2003).

There are many studies which try to determine the effective dose and effects on feeding (Rabbitfish Siganus lineatus Soto and Burhan-ud-Din, 1995) in different fish species. In this study, after two hours of clove oil application, clownfish fish and swordfish were fed successfully; however, after phenoxyethanol application the fish were fed the following day in any case.

In the studies carried out with phenoxyethanol; the shorter induction time and the longer recovery time were observed (rabbitfish, Siganus rivulatus, Soto and Burhanud-Din, 1995; marbled spinefoot, Ghanawi et al., 2013; Rainbow Trout Oncorhynchus mykiss, Y1ldiz et al., 2013). Furthermore, as the dose increased in Senegalese sole (Weber et al., 2009), the time of inductions and the time of recovery lessened. In this study, in all dose of phenoxyethanol induction was under 150 seconds and the more the dose was, the shorter induction time was. In recovery, recovery realized in all dose/concentrations under 300 seconds in total time and as dose/concentration increased, recovery time increased.

In our study, it was found that as the dose/concentration was increased in clove oil application, the time of induction decreased. The similar situation was also seen in rabbit fish (Siganus rivulatus) (Soto and Burhan-ud-Din, 1995; Ghanawi et al., 2013), Rainbow Trout (Oncorhynchus mykiss) (Y1ldiz et al., 2013) species. It was observed that the recovery from anaesthesia of fish treated with clove oil was longer than the other anestesic (rabbitfish. Siganus rivulatus (Soto and Burhan-ud-Din, 1995; Keene et al., 1998) in juvenile Russian sturgeon, Mylonasa et al. (2005) in European sea bass (Dicentrarchus labrax) and gilthead sea bream (Sparus aurata), Munday and Wilson (1997) in coral reef fish (Pomacentrus amboiensis) and Feng et al. (2011) in juvenile Siberian sturgeon; rainbow trout, Oncorhynchus mykiss (Y1ldiz et al. (2013); channel catfish, Ictalurus punctatus (Waterstrat, 1999). Besides that, there was an inverse proportional dependence between recovery time and clove oil concentration in rabbitfish (Siganus rivulatus) Ghanawi et al. (2013) and in pike (Esox lucius L.) Zaikov et al. (2008). In Senegalese solea (Weber et al., 2009) the time of recovery was independent of the amount of dose. According to Mylonasa et al. (2005), because the fish exposed to high amounts of dose induced rapidly, they were taken to recovery phase without being kept in anesthetics for long. The fact that recovery time takes long in fish which are applied anesthetic may be an advantage during the manual intervention of many fish (Woody et al. 2002). Furthermore, lessening fish stress decreases oxygen consumption because it decreases the metabolic rate and swimming speed during transportation (Chandroo et al., 2005). As a result in short-term applications on clownfish, the ideal amount of anesthetic substance might be $0.4 \mathrm{ml} / \mathrm{L}$ in phenoxyethanol, and $1 \mathrm{ml} / \mathrm{L}$ in clove oil. As a result for swordfish, it was clearly seen that both anesthetic substances could be used for both female and male individuals of swordtail fish. When the induction and recovery times of both substances were considered in terms 
of usability in female and male individuals of swordtail fish, there were no big differences. In this context, it was found out that in ideal anesthetic substance classification, phenoxyethanol dose in which the time of induction was below $3 \mathrm{~min}$ and the timing recovery was below $5 \mathrm{~min}$ was $1 \mathrm{ml} / \mathrm{L}$ in short-term applications in swordtail fish. The rate for clove oil was found to be $2 \mathrm{ml} / \mathrm{L}$. The fact that recovery took long in anesthetized fish might be seen as an advantage in manual intervention (Woody et al. 2002). Furthermore, decreasing the stress of fish decreases the oxygen consumption because it decreases the metabolic rate and swimming speed (Chandroo et al., 2005).

\section{CONCLUSION}

The suggested dose of clove oil in this study was $6 \mathrm{ml} / \mathrm{L}$ for female and male fish. Similarly, the dose of phenoxy ethanol was $5 \mathrm{ml} / \mathrm{L}$. It is apparent that when the economic criteria in anesthetic substance classification are considered, clove oil is more advantageous than phenoxyethanol. In terms of environmental interaction, clove oil should be important for aquaculture.

\section{Statement of conflict of interest}

Authors have declared no conflict of interest.

\section{REFERENCES}

Ajith Kumar, T.T., Setu, S.K., Murugesan, P. and Balasubramanian, T., 2010. Studies on captive breeding and larval rearing of clownfish Amphiprion sebae (Bleeker 1853) using estuarine water. Indian J. Mar. Sci., 39: 114-119.

Ajith Kumar, P. and Balasubramanian, 2009. Broodstock development, spawning and larval rearing of the false clownfish, Amphiprion ocellaris in captivity using estuarine water. Curr. Sci., 97: 1483-1486.

Allen, G.R., 1980. Anemone fishes of the World: Species, care and breeding. Aquarium Systems, Mentor, $\mathrm{OH}, \mathrm{USA}$.

Anderson, G., McKinley, R.S. and Colavecchia, M., 2011. The use of clove oil as an anesthetic for rainbow trout and its effects on swimming performance. N. Am. J. Fish. Manag., 17:301-307.

Avella, M.A., Olivotto, I., Gioacchini, G., Maradonna, F. and Carnevali, O., 2007. The role of fatty acids enrichments in the larviculture of false percula clownfish, Amphiprion ocellaris. Aquaculture, 273: 87-95. https://doi.org/10.1016/j. aquaculture.2007.09.032

Chandroo, K.P., Cooke, S.J., Mckinley, R.S. and Moccia, R.D., 2005. Use of electromyogram telemetry to assess the behavioral and energetic responses of rainbow trout, Oncorhynchus mykiss (Walbaum) to transportation stress. Aquacult. Res., 36: 1226-1238. https://doi.org/10.1111/j.13652109.2005.01347.x

Dhaneesh, K.V., Nanthini Devi, K., Ajith Kumar, T.T. and Balasubramanian, T., 2012. Breeding, embryonic development and salinity tolerance of Skunk clownfish Amphiprion akallopisos. J. King Saud Univ. Sci., 24: 201-209. https://doi. org/10.1016/j.jksus.2011.03.005

Feng, G., Zhuang, P., Zhang, L., Kynard, B., Shi, X., Liu, J. and Huang, X., 2011. Effect of anaesthetics MS-222 and clove oil on blood biochemical parameters of juvenile Siberian sturgeon (Acipenser baerii). J. appl. Ichthyol., 27: 595-599. https://doi. org/10.1111/j.1439-0426.2011.01711.x

Ghanawi, J., Monzer, S. and Saoud, I.P., 2013. Anaesthetic efficacy of clove oil, benzocaine, 2-phenoxyethanol and tricaine methanesulfonatein juvenile marbled spinefoot (Siganus rivulatus). Aquacult. Res., 44: 359-366. https://doi. org/10.1111/j.1365-2109.2011.03039.x

Gopakumar, G., George, R.M. and Jasmine, S., 2001. Hatchery production of the clownfish Amphiprion chrysogaster. In: Perspective in Mariculture (eds. N.G. Menon and P.P. Pillai). The Marine Biological Association of India, Cochin, pp. 305-310.

Gutiérrez-Rodríguez, C., Morris, M.R., Dubois, N.S. and Queiroz, K., 2007. Genetic variation and phylogeography of the swordtail fish Xiphophorus cortezi (Cyprinodontiformes, Poeciliidae). Mol. Phylogen. Evol., 43: 111-123.

Hasan, M., Pinky, N.I., Kabir, M.A., Ahmed, S. and Rashid, M.M., 2013. Performances of 2 phenoxyethanol and quinaldine with oxygen in the live truck transportation of rohu fingerlings. $J$. Asiat. Soc. Bangladesh, Sci., 39: 201-209.

Haschick, R.D., 1998. Reproductive behaviour of the surviour of the skunk clownfish, Amphiprion akallopisos, under captive conditions. MSc. thesis. Rhodes University, pp. 102.

Iversen, M., Finstad, B., Mckinley, R.S. and Eliassen, R.A., 2003. The efficacy of metomidate, clove oil, Aqui-STM and Benzoak ${ }^{\circledR}$ as anaesthetics in Atlantic salmon (Salmo salar L.) smolts, and their potential stress-reducing capacity. Aquaculture, 221: 549-566. https://doi.org/10.1016/S00448486(03)00111-X

Kayım, M.H., Çağırgan, H. and Güner, Y., 1999. The research of the effects of $17 \alpha$-methyltestosterone on the growth of swordtail fish (Xiphophorus 
helleri Heckel,1848). (in Turkish) J. Fish. aqua. Sci., 16: 31-46.

Keene, J.L., Noakes, D.L.G., Moccia, R.D. and Soto, C.G., 1998. The efficacy of clove oil as an anaesthetic for rainbow trout, Oncorhynchus mykiss (Walbaum). Aquacult. Res., 29: 89-101. https://doi. org/10.1111/j.1365-2109.1998.tb01113.x

Kwak, H., Bae, M.O., Lee, M.H., Lee, Y.S., Lee, B.J., Kang, K.S., Chae, C.H. and Sung, H.J., 2001. Effects of nonylphenol, bisphenol a, and their mixture on the viviparous swordtail fish (Xiphophorus helleri). Environ. Toxicol. Chem., 20: 787-795.

Liang, X., Nie, X., Ying, G., An, T., Li, L. 2013. Assessment of toxic effects of triclosan on the swordtail fish (Xiphophorus helleri) by a multibiomarker approach. Chemosphere 90 (2013) 1281-1288.

Marking, L.L. and Meyer, F.P., 1985. Are better anesthetics needed in fisheries? Fisheries, 10: 2-5. https://doi.org/10.1577/15488446(1985)010<0002:ABANIF $>2.0 . C O ; 2$

Munday, P.L. and Wilson, S.K., 1997. Comparative efficacy of clove oil and other chemicals in anaesthetization of Pomacentrus amboinensis, a coral reef fish. J. Fish Biol., 51: 931-938. https:// doi.org/10.1006/jfbi.1997.0498

Mylonasa, C., Cardinalettia, G., Sigelakia, I. and Polzonetti-Magnib A., 2005. Comparative efficacy of clove oil and 2-phenoxyethanol as anesthetics in the aquaculture of European sea bass (Dicentrarchus labrax) and gilthead sea bream (Sparus aurata) at different temperatures. Aquaculture, 246: 467-481. https://doi.org/10.1016/j.aquaculture.2005.02.046

Olivotto, I., Stefano, M.D., Rosettia, S., Cossignanic, L., Pugnalonid, A., Giantomassid, F. and Carnevalia, O., 2011. Live prey enrichment, with particular emphasis on HUFAs, as limiting factor in false percula clownfish (Amphiprion ocellaris, Pomacentridae) larval development and metamorphosis: Molecular and biochemical implications. Comp. Biochem. Physiol. Part A: Mol. Integr. Physiol., 159: 207-218. https://doi. org/10.1016/j.cbpa.2011.02.004

Olivotto, I., Cardinali, M., Barbaresi, L., Maradonna, F. and Carnevali, O., 2003. Coral reef fish breeding: The secrets of each species. Aquaculture, 224: 6978. https://doi.org/10.1016/S0044-8486(03)002072

Park, M.O., Hur, W.J., Im, S.Y., Seol, D., Lee, J. and Park, I.S., 2008. Anaesthetic efficacy and physiological responses to clove oil-anaesthetized kelp grouper Epinephelus bruneus. Aquacult. Res., 39: 877-884. https://doi.org/10.1111/j.1365-2109.2008.01941.x

Pomeroy, R.S. and Balboa, C., 2004. The financial feasibility of small-scale marine ornamental aquaculture in the Philippines. Asian Fish Sci., 17: 365-376.

Ross, L.G. and Ross, B., 2008. Anaesthetic and sedative techniques for aquatic animals, $3^{\text {rd }}$ Edition. Blackwell Science Ltd., London, pp. 159-240. https://doi.org/10.1002/9781444302264

Soto, C.G. and Burhan-ud-Din, 1995. Clove oil as a fish anaesthetic for measuring length and weight in rabbitfish (Siganus lineatus). Aquaculture, 136: 149-152. https://doi.org/10.1016/00448486(95)01051-3

Summerfelt, R.C. and Smith, L.S., 1990. Anaesthesia, surgery and related techniques. In: Methods for fish biology (eds. C.B. Schreck and P.B. Moyle). American Fisheries Society, Bethesda, pp. 213272.

Tamaru, C.S., Cole, B., Bailey, R., Brown, C. and Ako, H., 2001. A manual for commercial production of the swordtail, Xiphophorus helleri. CTSA Publication Number 128. http://www.ctsa.org/files/ publications/CTSA_1286316728616527475841. pdf (Accessed on: 7/2/2014).

Tort, L., Puigcerver, M., Crespo, S. and Padros, F., 2002. Cortisol and haematological response in sea bream and trout subjected to the anaesthetics clove oil and 2-phenoxyethanol. Aquacult. Res., 33: 907-910. https://doi.org/10.1046/j.1365-2109.2002.00741.x

Wabnitz, C., Taylor, M., Green, E. and Razak, T., 2003. From ocean to aquarium. UNEP-WCMC, Cambridge, UK.

Waterstrat, P.R., 1999. Induction and recovery from anesthesia in channel catfish (Ictalurus punctatus) fingerlings exposed to clove oil. $J$. World Aquacult. Soc., 30: 250-255. https://doi. org/10.1111/j.1749-7345.1999.tb00872.x

Weber, R.A., Peleteiro, J.B., García Martín, L.O. and Aldegunde, M., 2009. The efficacy of 2-phenoxyethanol, metomidate, clove oil and MS222 as anaesthetic agents in the Senegalese sole (Solea senegalensis Kaup 1858). Aquaculture, 288: $\quad 147-150 . \quad \mathrm{https}: / /$ doi.org/10.1016/j. aquaculture.2008.11.024

Woody C.A., Nelson, J. and Ramstad, K., 2002. Clove oil as an anaesthetic for adult sockeye salmon: field trials. J. Fish Biol., 60: 340-347. https://doi. org/10.1111/j.1095-8649.2002.tb00284.x

Yasır, I. and Q1n, J.G., 2009. Impact of background on color performance of false clownfish, Amphiprion ocellaris, Cuvier. J. World Aquacult. 
Soc., 40: 724-734. https://doi.org/10.1111/j.17497345.2009.00292.x

Yasır, I. and Qın, J.G., 2010. Effect of dietary carotenoids on skin color and pigments of false clownfish, Amphiprion ocellaris, Cuvier, J. World Aquacult. Soc., 41: 308-318. https://doi.org/10.1111/j.17497345.2010.00373.x

Yıldız, M., Kayım, M. and Akın, S., 2013. The anesthetic effects of clove oil and 2-phenoxyethanol on rainbow trout (Oncorhynchus mykiss) at different concentrations and temperatures. Iranian J. Fish. Sci., 12: 947-961.

Zaikov, A., Iliev, I. and Hubenova, T., 2008. Induction and recovery from anaesthesia in pike (Esox lucius L.) exposed to clove oil. Bulgarian J. agric. Sci., 14: $165-170$. 